\title{
Penal Mediation from the Perspective of Criminal Law (Study of the Settlement of Criminal Cases by Mediation)
}

\author{
Dwi Hapsari Retnaningrum*1 \\ ${ }^{1}$ Faculty of Law, Jenderal Soedirman University, Purwokerto, Central Java, Indonesia
}

\begin{abstract}
Mediation is a method to solve cases by involving third parties, commonly used in civil law. The usage of mediation in criminal law, aims to make the perpetrators aware that their criminal act is wrong and to percieved that the victims need to be reinstated. Therefore it is important to understand what the background of the usage of mediation in criminal crime cases and how the prospect of mediation in the future is. The purpose of this paper is to know how penal mediation is seen from the perspective of criminal law, while the benefit is to contribute thoughts in terms of criminal law. The method used to solve the problem is juridical normative method and empirical method. Based on the results of the study, it is known that penal mediation which is basically undisclosed in the field of criminal law-practically has been used, thus the prospect of mediation will be widely used in the future. In several laws, the provisions of mediation are also registered. Penal mediation from the perspective of criminal law can be used as one of the means of settlement of criminal cases.
\end{abstract}

\section{Introduction and Literature Review}

The police as the first door to enter criminal cases have an important role. In reality, the cases handled are not equitable with the number of police available, so that the criminal justice system which is expected to be the last stronghold of justice seekers is not fulfilled. The police are a living law, through this police promises and legal objectives to secure and protect the public become reality (1). Another factor is the factor of law enforcement officers themselves. The main problem of law enforcement actually lies in the factors that might be influenced it (2). One way of law enforcement is with criminal law. According to George P Fletcher (4)

"without punishment and institutions designed to measure and carry out punishment, there is no criminal law."

According to Moeljatno criminal law is part of the overall law that applies in a country, which establishes the basics and rules for:

1) Determine which action should not be carried out, which are prohibited, accompanied by a threat or sanction in the form of a particular criminal who violates the prohibition

2) Determine when and in what cases to those who have violated the prohibitions that can be imposed or imposed as punishment as threatened

3) Determine in a way how the imposition of a criminal offense can be carried out if a person is suspected of having violated the prohibition (3)

Criminal law from a nation is a very chief indication to understand the level of the nation's civilization, because it implies how the nation's views on ethics (morality), social, and religious morality (4)

In principle, mediation is unknown in criminal law, but in Article 82 of the COUP there is a regulation concerning the settlement of cases outside the court, namely Afdoinen buiten process, limited to criminal acts that are only threatened with criminal penalties.

Penal mediation is a mediation in criminal cases. According to Barda Nawawi Arief (5) the background to the idea of the inclusion of mediation ideas or discourses in criminal cases, some are related to ideas of criminal

* Corresponding author : retnaningrumd@gmail.com 
reform (reason reform), and some are associated with pragmatism problems. The context of the settlement of cases outside the court through its peak judicial mediation is expected to suppress the accumulation of cases (conqestion) in court, especially at the Supreme Court level. (6)

Criminal mediation focuses on committed mistakes and aims to make the perpetrators aware that the crime they once committed was wrong and also made them aware that the victim needed to be reinstated (7).

\section{Objective of the Study}

The purpose of this research is to understand how mediation is viewed from the perspective of criminal law while mediation is still undisclosed in criminal law, and whether in police practice the Banyumas POLRES applies mediation.

\section{Methodology}

The method used in this study is sociological / non-doctrinal juridical. By using primary and secondary data. Primary data is obtained from interviews with respondents (police). Secondary data comes from primary, secondary, and tertiary materials. Research location at Banyumas Police Station. Qualitative data analysis with descriptive and prescriptive properties. Approach method with law approach and case approach. Conclusion with the induction method. According to Soetandyo Wignjosoebroto, in the non-doctrinal study of material logic with its inductive syllogism that is commonly used (9)

\section{Discussion}

The practice of resolving criminal cases outside the court so far has no formal legal basis, so cases often formally have a peaceful settlement (although through customary law), but still proceed to the court in accordance with applicable law. (6). From the results of Taufiqurrohman Abiddanwa's research, the criminal law policy in overcoming criminal acts through settlement efforts outside the positive legal process is currently only a small part while the others are still oriented towards formal settlement (10).

Provisions of positive law in Indonesia (ius constitutum) concerning mediation, including Law number 30 of 1999 concerning Arbitration and Alternative dispute resolution, Law Number 32 of 2009 concerning Environmental Protection and Management, Law Number 8 of 1999 concerning Consumer Protection, Law No. 39 of 1999 concerning Human Rights, Law No. 36 of 2009 concerning Health, and there are still several mediation provisions spread in other laws. In the field of civil law, mediation must be carried out before the judge examines the case, this is regulated in the Supreme Court Regulation of the Republic of Indonesia Number 1 of 2016. In criminal cases, the settlement outside the court is done if :

1. the offender is a child, namely with diversion. Diversion is the transfer of settlement of child cases from prosecution of criminal justice to prosecution outside criminal justice. (Law number 11 of 2012 concerning the juvenile justice system).

2. article 82 Paragraph (1) of the Indonesian Criminal Code, which formulates the authority to prosecute violations that are threatened with fines only, to be deleted, if the maximum fine and costs incurred are paid if the prosecution has been started, with the authority of the official appointed by the law general rules, and in the time set by him.

Based on the results of research at the Banyumas Resort Police, results were obtained :

First, according to the police the settlement of criminal cases with Restorative Justice (mediation) is very good, because the legal purpose of Restorative Justice if implemented with the procedure will be fulfilled from the three aspects, justice, usefulness, and legal certainty. However, it only applied for child cases. Other cases have not exist yet. Because there is no legal basis even though there is a discretion it still cannot contradict the prevailing regulations. Restorative justice has two sides, on the one hand it is a concept and on the other hand its implementation. The implementation may be very good in certain cases, such as persecution, embezzlement, fiduciary. From this statement it appears that the police only carry out what is in the law of the juvenile justice system. The police did not dare to apply to other cases, even though according to the police it was denied. Associated with the legal system theory of Lawrence Friedman, in the legal structure, the police as law enforcement officers only apply what the law says. There is no independence from the police acting on its own discretion. Although the main law of the police gives authority to the police to carry out discretion. Secondly, the police who conduct mediation are at the Integrated Service Center (PPT). PPT is a place of service, complaint, and examination specifically for child or female victims. Because child perpetrators are done with diversion, mediation is done in the PPT room. Third, the legal basis for the settlement of cases with mediation at the Banyumas POLRES is based on the National Police Regulation, the Law on the Protection of Women and Children, and the Juvenile Justice System Law. Fourth, the settlement mechanism is in 3 stages, namely the Investigation Stage, the Prosecution Stage, and the Trial Stage in the Court. Usually the settlement is done at PPT, 
then at the mediation police station, the results of the mediation are brought to court to be asked for confirmation. Fifth, the role of the police in the mediation process is as a neutral mediator, its role is as mandated by the Juvenile Justice System Law. Only convey what is the duty of the investigator. Sixth, the police need a legal umbrella as the basis for conducting mediation. From the police's request for a legal umbrella, it was clear that the police were only implementing the law. The police should have given discretion, dare to act with the aim for the good of victims and perpetrators.

According to Agus Raharjo, the settlement of criminal cases through non-litigation channels is an alternative route that will help reduce the accumulation of cases in the court and congestion of SPP in handling crimes. models There are several things that make the settlement of criminal cases through non-litigation channels said to be quasi-criminal because there are civil elements but are used to resolve criminal cases (11). Non litigation pathways that are widely used by the police are mediation.

The mediation model used is the victim offender mediation model. This mediation model is one model known in the judiciary with a restorative justice approach.

There is a significant difference between resolving disputes through the court and outside the court. According to Marcus Priyo Gunarto, each of these ways of solving has characteristics of differences. (12)

The characteristics of dispute resolution through the court are :

1. Takes a long time

2. Demand large costs;

3. The process is very formal;

4. Decisions are not always satisfying;

5. Coercive;

6. Based on rights (right based);

7. Can damage existing business / social relations;

8. Can cause prolonged conflict

9. Backward looking (looking back, not forward)

10. Open / publicity (someone's reputation)

While the characteristics of dispute resolution through ADR :

1. The nature of volunteerism in the process;

2. Quick procedure;

3. Non judicial decision (not punish);

4. Secret nature (privatization of disputes);

5. Flexibility in designing the terms of dispute resolution;

6. Save time and costs;

7. Protection and recovery of existing relationships;

8. Ease of carrying out the outcome of the settlement;

9. It's easier to predict results.

The settlement of cases through an off-court process results in a "win-win solution" agreement, guaranteed confidentiality of the parties' disputes, avoidance of delays caused by procedural and administrative matters, comprehensively resolving problems in togetherness and maintaining good relations.

\section{Conclusion}

In criminal cases, in principle, mediation is still undisclosed. Mediation is known in the realm of civil law, therefore the provision on mediation are listed in various laws. Although in criminal cases mediation is still undisclosed, the police at the Banyumas POLRES use the settlement of cases that are the perpetrators of children. This is based on the Law on the Criminal Justice System of the Child, even though the law is called diversion. With the implementation of mediation in criminal cases involving children, the police should be able to apply in other criminal cases, not having to await for a legal umbrella so that a better criminal justice system can be created. 


\section{References}

1. S. Rahardjo, Masalah Penegakan Hukum suatu tinjauan sosiologis (Sinar Baru, Bandung)

2. S. Soekanto, Faktor-faktor yang mempengaruhi penegakan hukum (Raja Grafindo, Jakarta, 2004)

3. Moeljatno, Asas-asas hukum pidana (Rineka Cipta, Jakarta, 2005)

4. G. P. Fletcher, Basic concepts of criminal law, (Oxford University Press, New York, 1998)

5. Soedarto, Hukum Pidana 1, (Yayasan Soedarto, Semarang, 1987)

6. B. Nawawi Arief, Mediasi Penal Penyelesaian Perkara di Luar Pengadilan, (Pustaka Magister, Semarang)

7. L. Mulyadi, Mediasi Penal dalam sistem peradilan pidana (Alumni, Bandung, 2015)

8. E. O.S. Hiariej, Prinsip-prinsip Hukum Pidana edisi revisi, (Cahya Atma Pustaka, Yogyakarta)

9. S. Wignjosoebroto, Keragaman Dalam Konsep Umum, Tipe, Kajian, Dan Metode Penelitiannya (dalam Bernard Arief Sidharta, Butir-Butir Pemikiran Dalam Hukum, (Refika Aditama, Bandung, 2008)

10. T. Abidanwa, Jurnal Pembaharuan Hukum, 111.1 (2016)

11. A. Raharjo, JMH, 20.1 (2008).

12. M. Priyo Gunarto,2016, Ceramah di KORLANTAS MABES POLRI, Jakarta 